\title{
How does investing in cheap labour countries affect performance at home? Firm-level evidence from France and Italy
}

\author{
By Giorgio Barba Navaretti*, Davide Castellani\#, and Anne-Célia Disdier \pm
}

*Università di Milano and Centro Studi Luca d'Agliano

\#Università di Perugia and Centro Studi Luca d'Agliano

\pm INRA, UMR Economie Publique INRA-AgroParisTech, 16 rue Claude Bernard, 75231 Paris

Cedex 05, France. email: Anne-Celia.Disdier@agroparistech.fr

\section{Forthcoming in Oxford Economic Papers}

\begin{abstract}
Transferring low tech manufacturing jobs to cheap labour countries is often seen by part of the general public and policy makers as a step into the de-industrialisation of the European economies. However, recent contributions have shown that the effects on home economies are rarely negative. Our paper contributes to this literature by examining how outward investments to developing and less developed countries (LDCs) affect home activities of French and Italian firms that turn multinational in the period analysed. The effects of these investments are also compared to the effects of investments to developed economies (DCs). The analysis is carried out by using propensity score matching. We find no evidence of a negative effect of outward investments to LDCs. In Italy they have a positive long term effect on value added and employment. For France we find a positive effect on the size of domestic output and employment.
\end{abstract}

JEL Classification: F23, D21, C14 


\section{Introduction}

Transferring low tech manufacturing jobs to cheap labour countries is often seen as a step into the de-industrialisation of European economies. Consequently, policy makers have increasingly been proposing measures aimed at limiting these types of international activities. In May 2005, the European Parliament's Regional Development Committee has expressed a strong support for the European Commission proposal to impose financial penalties on firms which have received EU funding but then decide to relocate. The Committee also asked for legal measures to ensure that firms receiving European subsidies do not relocate abroad for a 'long and predetermined' period. In France, the 2005 budget offered subsidies to firms that transferred to France activities previously located outside of the European Union. Firms located in French regions highly specialized in one industrial activity and suffering from a high level of unemployment could also receive subsidies. Similarly, in Italy a law, passed in 2005, prevents firms that transfer a substantial part of their activities abroad from accessing subsidised public funds to support exports or foreign investments.

The central message of this paper is that the presumed negative effects of transferring part of production to cheap labour countries is not supported neither by theory - which is ambiguous nor by the available empirical evidence - which does not find negative effects. Rather, very often the effects of this investment are found to be positive, particularly when compared to the baseline scenario of maintaining all production in the home country. Specifically, this paper examines the impact of outward investment to cheap labour countries on home activities of a sample of French and Italian firms. In particular, it looks at the impact on the size (employment, gross output, and value added) and on the efficiency (total factor productivity) of economic activities maintained at home by the investing firms. ${ }^{1}$

Our analysis is nested in a broad model of investment decision, whereby a firm which has never invested abroad before faces a three way choice: staying national, investing in a cheap labour country, which we proxy with developing and less developed countries (LDCs), or investing in developed countries (DCs). It is therefore possible to examine the effect of investing in a cheap labour country in comparison to the baseline of staying at home and also assess if the effects are different when a firm invests in an industrialised economy. This distinction according to the destination of the investment is important, as often the motives and consequently the

\footnotetext{
${ }^{1}$ It is worth mentioning that our analysis is limited to the effects of investing abroad on home activities of the investing firms. In order to accurately assess the effect on the overall home economy, one should also account for any effect that offshoring would cause to other domestic firms (such as competitors, buyers, and suppliers) and to distributional effects on different individuals (such as workers with different skills).
} 
effects of investing in the two areas can be radically different. Whereas investments in cheap labour countries are likely to be aimed at reducing production and specifically labour costs through the geographical fragmentation of the production chain (vertical investments), investments in large and developed economies normally aim at tapping the local market through a partial duplication of the activities carried out at home (horizontal investments). The effects on the home activities also take place through different channels, a change in factor use for vertical investments and a scale effect for horizontal ones. The empirical strategy we have devised, therefore, also allows some considerations on the role of these different channels.

Our work builds on Barba Navaretti and Castellani (2003, 2008). These earlier papers focused on Italy and looked at the effects of foreign investment independently of its destination. They found that firms investing abroad have higher total factor productivity and output growth, and no significant differences in employment growth than firms not investing abroad. They also showed that in order to isolate the effects of investing abroad on performance, it is important to construct an appropriate counterfactual: what would have happened to firms if they had not invested abroad. This was done by using propensity score matching. This paper has two major differences compared to these earlier works. First, it classifies investments according to their destination. It therefore disentangles the specific effect of investing in cheap labour countries. To do so it extends propensity score matching to the possibility of multiple treatment: investing in a developing country, investing in a developed country or not investing abroad. Second, it extends the analysis to France, therefore providing a broader picture of this process in continental Europe. $^{2}$

The key finding is that, in contrast with the overwhelming public and policy concerns, there is no evidence of negative effects of outward investments to cheap labour countries on home output, employment, and productivity of the investing firms. Rather, in Italy they enhance the efficiency of home activities, with also positive long term effect on value added and employment growth. This pattern is consistent with the theory of vertical investment. The geographical fragmentation of production is expected to change the factor mix of home activities, with a concentration on skill and technology intensive tasks. This may lead to an increase in productivity and value added in the short term. The consequent gains in efficiency could then enhance the competitiveness of investing firms, leading to a long term expansion of employment. As for France, we find a positive effect on the size of domestic activities, as both output and employment grow after the investment, but no effects on productivity. Investments to developed

\footnotetext{
${ }^{2}$ Note that this paper focuses on FDI and not on other looser forms of transferring production activities abroad, like for example subcontracting.
} 
economies have similar effects for both countries. Scale increases in terms of employment and output and it then eventually trickles down into higher productivity in the longer term. The implication of these results is that policies aimed at limiting investments to cheap labour countries may deprive firms of an important strategic option with long term positive effects on the domestic economy.

The remainder of this paper is structured as follows: Section 2 presents the literature. In section 3, we present our empirical setting. The data are described in section 4 . The results of the empirical application are detailed in section 5. Section 6 concludes.

\section{Literature}

This section briefly reviews what we can learn from the available literature on the effects of foreign direct investment (FDI) on home activities, and particularly their size (output, value added, and employment) and their efficiency (productivity).

\subsection{Analytical framework}

The theory on outward FDI has ambiguous predictions for what concerns their home effects. Both the models of Horizontal FDI (HFDI) and Vertical FDI (VFDI) show that several channels are at work. These channels are related to three different domains: (i) the product market; (ii) the factor market; (iii) technology transfers. The model of VFDI, which implies product fragmentation according to differences in factor intensities, provides a more fitting representation of North-South investment flows, across countries with different factor endowments. However, many investments to least developed areas are also aimed at entering local markets rather than simply reducing production costs. We therefore also discuss the home implications of HFDI.

Consider first the product market: how does investing abroad affects the competitiveness and consequently output and market share of the investing firm. In a vertical FDI, the short-term effect on home output is supposed to be negative as part of what was initially done at home gets relocated abroad. However, in the longer term, this effect could become positive as firms, by reducing production costs, increase competitiveness, gain market shares and also expand home output. As shown in Barba Navaretti and Venables (2004), an accurate analysis of the effect on home output must take into account an appropriate counterfactual. Thus, simply looking at the dynamic of home output following the investment might not be particularly conclusive. If firms do not transfer part of their activities and if other firms do, as new low cost locations become available to foreign investors, integrated production in the home country could likely become a 
non viable option and the firm be pushed out of the market all together. As for HFDI, potential export flows get replaced by local production abroad. Consequently, home output declines. Yet, this effect could be reversed if the affiliate uses inputs or other complementary products from the home plant. Also, demand for headquarter services at home could rise with the expansion of foreign activities.

Regarding factor market effects, the main concern is for the labour market, and more precisely for the effects on overall labour demand, on skill composition and on factor prices. Overall labour demand is derived from output demand. If output increases, this has positive effects on home employment both for VFDI and HFDI. But investments abroad may also change factor composition and particularly the skill mix of the labour force. Vertical FDI could reduce the demand for unskilled labour in the home economy and increase the demand for skilled labour (Helpman, 1984; Helpman and Krugman 1985; Feenstra and Hanson 1996). Factor prices should also be affected by these changes in factor demand. For horizontal FDI, the effects are less clear and the theory does not provide clear predictions on the sign of the changes in home factor demand.

The last issue is the technology sourcing. Both HFDI and VFDI could lead to a technology transfer to home plants, in particular if multinational firms (henceforth MNEs) locate their plants in knowledge intensive areas (Cantwell, 1995). The scale effect discussed above may also have effects on efficiency. If output rises we may expect an increase in the extent of exploitation of economies of scale in home plants. In VFDI, parent company productivity could also increase following the overall cost-efficiency improvement of the MNE and the increasing specialisation in high-value added activities at home.

Summing up, the available theory highlights several channels through which outward FDI may have positive or negative effects on performance at home, but no clear prediction can be made on their net effects and it boils down to an empirical question.

\subsection{Available evidence}

Several earlier empirical works have examined the effects of outward FDI on output (Blonigen, 2001; Head and Ries, 2001; Desai et al., 2005), home employment (Blomström et al., 1997; Brainard and Riker, 1997a and 1997b; Lipsey, 1999; Bruno and Falzoni, 2000; Braconier and Ekholm, 2002; Hanson et al., 2003; Mariotti et al., 2003; Marin, 2004; Becker et al., 2005; Konigs and Murphy, 2006), productivity (Braconier et al., 2001; van Pottelsberghe de la Potterie and Lichtenberg, 2001). They generally find that the effect of FDI is positive or that short term 
costs get offset in the longer term. ${ }^{3}$ However, these studies are based on sector/regional evidence or, when addressing the question at the firm-level, only focus on the activities of MNEs and thus fail to take into account the appropriate counterfactual to this problem. This issue pops-up rather clearly from a recent work by Harrison and McMillan (2006) on a large sample of US multinationals for the years 1977 to 1999. Unlike other previous works on US data, they find that employment in affiliates in low-income countries tend to substitute for employment in the US, while employment in high-income affiliates is generally complementary to jobs at home. However, the study also reports that firms investing in low-income countries have a higher probability to survive with respect to other US multinationals not investing abroad. This suggests that it is not only important to correlate the dynamics of employment (and other performances) at home with outward investments, but it is key to assess what would have happened in the case investment had not taken place. ${ }^{4}$

Only recently researchers have started looking at this issue by comparing investing and non investing firms, so as to isolate the effects of opening up a foreign plant. Barba Navaretti and Castellani (2003) and Egger and Pfaffermayr (2003) are the first papers to use matching estimators to assess the home effects of outward investment. The former is based on Italy and examines the comprehensive effect of new investments on productivity, output, and employment. It finds that when firms open up a foreign plant, total factor productivity and output increase at home, with no significant effects on employment. The latter examines the effect on tangible and intangible investments in Austria. It finds that firms investing abroad also raise their investments in R\&D and in intangible assets at home. None of these papers, though, control for the destination of the investment. This is done in this work and also in two recent contributions: Debeare et al. (2006) which looks at the employment effects in Korea and Hijzen et al. (2006), which examines the effects on employment, skill intensity, and productivity in France. These works show that investments have different home effects according to whether foreign plants are set up in low or high income countries. In particular, they find large positive effects on home employment when firms invest in advanced countries, whereas investments to developing countries have positive effects only in the longer term. In neither cases though, there is evidence that investments in cheap labour countries harm economic activities at home. In the case of Italy, Castellani et al. (2008) estimate a dynamic panel specification of overall employment and of the share of white-collar workers as a function of foreign investor status. They find no evidence of

\footnotetext{
${ }^{3}$ See Mankiw and Swagel (2006) for a detailed survey of empirical works on the US and Molnar et al. (2007) for a recent review of the evidence in OECD countries.

${ }^{4}$ Similarly, Simpson (2007) finds that UK MNEs are less likely to shut down plants in the UK, than other UK firms, although within UK MNEs plants carrying out low-skill activities are more likely to close.
} 
any negative effects on employment and some evidence of skill-upgrading in firms investing toward Central and Eastern European countries. We will see that these results are also in line with our findings.

Our work is nested in the broader debate on the effects of manufacturing and service offshoring, which has grown considerably in the last few years, mostly in the US and in the UK. In most studies offshoring is captured by the share of imported components on total inputs or sales at the firm or at the industry level. This approach is complementary to ours. On the one hand it provides a more comprehensive measure of foreign production, in that offshoring can take place through both FDI or arm length agreements with local firms. On the other hand, though, it does not capture the effect of investments which are not aimed at replacing domestic inputs and therefore do not generate imports of intermediates.

Amiti and Wei (2005), a study based on US and UK data, finds that, particularly for the UK, outsourcing has not led to employment losses neither in manufacturing nor in services. Boulhol and Fontagné (2006) analyse how far the observed de-industrialisation in 16 OECD countries can be related to outsourcing. Their estimations suggest that net trade with low wage countries is associated with an average decrease of around two points in the manufacturing employment share between 1970 and 2002. However, this contribution represents only one-fifth of the deindustrialisation process over the period analysed. Görg et al. (2008) analyse the impact of outsourcing on productivity at the firm level for a sample of Irish firms. They find that the outsourcing of material inputs has a positive effect on the productivity of those firms which are also exporting. In contrast the effect of outsourced services is not significant. Some recent works have focused on the case of France, one of the two countries analysed in this paper. In a very detailed analysis based on different sources of data, Fontagné and Lorenzi (2005) show that relocations explain only $10 \%$ of the de-industrialisation process observed in France. Besides, according to this study, less than $3 \%$ of the stock of FDI has been set up with the aim of replacing home production. Also Aubert and Sillard (2005) find that offshoring accounts for a small amount of job losses in France. Between 1995 and 2001, only 2.4\% of total industrial jobs lost can be related to the foreign relocation of activities. In the case of Italy, Daveri and JonaLasinio (2007), using data from input-output tables, study the relation between off-shoring and productivity growth in the Italian manufacturing industries in 1995-2003. Their results indicate that the international outsourcing of intermediates within the same industry (which they define as 'narrow offshoring') is beneficial for productivity growth, while the offshoring of services is not. 


\section{Empirical setting}

The empirical implementation implies comparing the performance of a given firm which has transferred one or more stages of production to a foreign country, with the performance it would have had if it had kept integrated production at home. Of course the hypothetical benchmark of integrated production at home cannot be observed for firms which have fragmented production, and this poses several methodological problems. First, if we observe only MNEs we cannot single out the hypothetical benchmark: performance if the MNEs had not invested abroad. Second, if we observe only MNEs, we do not know if changes in performance are due to unobservable shocks equally affecting all firms, national and multinational alike. It is therefore important to benchmark MNEs to a sample of national firms. However, when comparing the performance of MNEs and national firms, we face a third problem: we do not know if differences are due to other characteristics of the two types of firms rather than to their being multinational or strictly national. In particular, foreign investments and performance are jointly determined. Given that investing abroad entices large costs, with imperfect financial markets only the (ex-ante) most productive firms will invest abroad. The recent theoretical literature on the decision to export and invest abroad with heterogeneous firms establishes a very clear link between ex-ante performance and international activities: entering international markets entail fixed costs and only the most profitable firms will be able to invest abroad (Helpman et al., 2004). Thus, if we observe that ex-post MNEs perform better than national firms, we do not know if this is so because of foreign investments or because these firms performed better anyway, even before the investment.

Figure 1 is derived from Clerides et al.'s (1998) paper on exporting firms' performance. We adapt it to the case of foreign investments. We depict average hypothetical trajectories in home performance for three types of firms: those which are always MNEs, i.e. with at least one foreign subsidiary during all the period observed; those which never have a foreign subsidiary in the period observed (NATIONALs) and those that open their first foreign subsidiary in the period observed and therefore switch from being national into being MNEs (SWs) at time $t$.

As mentioned above and according to the recent literature, MNEs perform better than national firms. More can be learned if we now focus on switching firms, those which invest for the first time at $t$. If the investment has a positive effect on productivity their trajectory becomes steeper at $t$ and performance eventually converges to the one of MNEs. Thus, our empirical question can be answered by comparing their trajectory after the investment to the one that they would have followed if they had not invested. If the investment does indeed improve performance, this hypothetical trajectory lies below the one of the switching firms after $t$, as 
represented by the dotted line in Fig. 1. This comparison is important, as if we just focus on effective performance, even if we observe that it improves, this could be the outcome of other factors which have nothing to do with the investment. Unfortunately, the dotted line cannot be observed and we need to proxy it. National firms are a good candidate for the counterfactual. However, the trajectory of the appropriate counterfactual should indeed differ from the one of switching firms just because of the different investment decision. Due to the fixed costs on entry on international markets, a self-selection process will occur and only firms possessing some intangible capital giving them a competitive edge over national firms will invest abroad (Dunning, 1993; Markusen, 1995). Thus, switching firms are ex-ante different from national ones and this difference may affect ex-post performance. If we want to isolate the effect of investing, we need therefore to build a counterfactual made of a subsample of national firms which are as similar as possible to firms which have invested abroad. As firms choose endogenously whether to invest or not, this counterfactual could not be draw randomly. To overcome the problem of self-selection we use the method of propensity score matching, which aims at re-establishing the conditions of a natural experiment with non-experimental data (Heckman et al., 1997; Blundell et al., 2004). ${ }^{5}$ The main idea is to estimate the probability of switching of each firm conditional on a number of observables (the propensity score). Then, for each of the firms which actually invest abroad, one can find one or more firms with a sufficiently close propensity score. The performance trajectory of this control group is the closest approximation to the dotted line.

In this paper we have the additional problem that we want to control if investments to cheap labour countries, presumably of a vertical type, nest into a more general model of foreign investment, which includes also investments to developed countries, most likely horizontal ones. ${ }^{6}$ For simplicity we dub cheap labour countries, which include developing, transition, and less developed economies, as LDCs and developed economies as DCs. Indeed firms face three options: staying at home, investing in LDC and investing in DC. Consequently, our outcome is not a binary indicator, and we face a multiple treatment problem (Lechner, 2001). We address this issue by estimating a multinomial logit and computing propensity scores for each of the three possible outcomes: not switching (denoted as outcome=0), investing in LDC (outcome=1),

\footnotetext{
${ }^{5}$ This methodology has already been used in international economics to evaluate the effects of exporting and of acquisitions on firms' performance and returns to scale by Wagner (2002), Girma et al. (2004), Girma and Görg (2004), Arnold and Javorcik (2005), Arnold and Hussinger (2005), and Girma et al. (2007) and in the context of the relation between FDI and firms' performance, employment and R\&D by Barba Navaretti and Castellani (2003), Egger and Pfaffermayr (2003), Debaere et al. (2006), and Hijzen et al. (2006).

${ }^{6}$ Admittedly, this model would include other modes of internationalisation, such as export and contractual modes of international production (such as licensing, outsourcing, and joint ventures), which we will not be able to control for in our empirical analysis.
} 
and investing in DC (outcome=2). With the propensity scores for choice 1 and 2, we can run the matching algorithm and find the appropriate counterfactual in both cases. Unlike the binary treatment case, when the outcome variable can take multiple values, each choice can be compared to more than one counterfactual. For example, when we evaluate the effect of switching into LDC (DC), we should take into account two possible counterfactual states: remaining national or switching into DC (LDC). Unfortunately, the low number of switching firms leaves very few choices of controls in the latter case and we could not obtain any accurate matching. Therefore, we will use only national firms as a counterfactual to both firms switching in LDC and in DC, and our analysis allows us to tell whether and how switching in LDC or in DC affect performance relative to the hypothetical alternative of remaining national.

Once we obtain adequate control groups for firms switching in LDC and in DC, we can compare their performance trajectory with the one of those actually switching, in order to gather an estimate of the effects of investing abroad. We do so by computing the difference between the switching and the counterfactual firms in the average mean of performance after the year of investment (which yields the average treatment effect on the treated, ATT), as indicated in the following equation:

$$
\hat{\alpha}_{A T T}=\bar{y}_{t+s}^{1}-\bar{y}_{t+s}^{0}
$$

where $\bar{y}_{t+s}^{1}$ is the mean performance of investing firms $s$ periods after switching and $\bar{y}_{t+s}^{0}$ is a weighted average of performance of the control group over the same period.

In addition to the standard ATT estimator, we also use the difference-in-difference estimator (DID). Whereas the ATT estimator compares post-investment performance for the two groups of firms, the DID estimator compares the difference between pre- and post-investment performance in both groups. In other words, it measures the difference in the change of the steepness of the performance trajectories for the two groups of firms. Formally, DID is given by:

$$
\hat{\alpha}_{D I D}=\left(\bar{y}_{t+s}^{1}-\bar{y}_{t-1}^{1}\right)-\left(\bar{y}_{t+s}^{0}-\bar{y}_{t-1}^{0}\right)
$$

where upper bars denote averages in each group performances the year before and $s$ years after the investment. DID estimator measures the differential performance in the group of investing firms relative to the non-investing ones, once ex-ante differences in performance are accounted for. ${ }^{7}$

\footnotetext{
${ }^{7}$ Like a first-difference estimator in linear panel data, the DID aims at eliminating unobserved heterogeneity which might not be captured by matching and can affect post-investment performance.
} 


\section{Sample and data}

The empirical analysis carried out in this paper relies on two samples of French and Italian national and multinational firms over the period 1993-2000. In the period under consideration, aggregate data (see Fig. 2) show that both France and Italy experienced a spectacular growth in their outward FDI stocks. At the aggregate level, this increase in the foreign activities of multinational firms is associated with an increase in labour productivity (especially for France) and a slight drop in employment. The empirical analysis carried out in this paper will exploit firm-level data to shed more light on this association and assess whether investing abroad is responsible for job losses and productivity gains in France and Italy.

The French sample of multinational firms is drawn from the 2002 version of the database 'Enquêtes filiales' maintened by the Direction of Foreign Economic Relations (DREE) of the French Ministry of Economic and Finances, which provides the list of all affiliates of French firms, with 20 employees or more, and reports for each of them the year of investment and the chosen country. Exploiting this information we were able to identify 602 multinational firms (i.e. with at least one foreign affiliate) in 1995 and 787 in 2000 (see Table 1). The rise in the number of multinationals suggests that some firms switched from being national to multinational during the period under investigation. The overall number of these 'switching firms' is $231 .{ }^{8}$ Our number of switching firms is in line with the one obtained by Hijzen et al. (2006), using a different dataset of French multinationals. Their sample includes 355 manufacturing firms that became multinationals during the 1987-99 period. In addition to switching firms, 297 firms of our sample that were already multinationals before 1995 invested in new foreign affiliates over the 1995-2000 period. We refer to all these 528 firms investing abroad as 'investing firms'.

Table 1 reports the sectoral distribution of the French multinational, investing and switching firms included in our sample. Parent companies are concentrated in a few sectors. In particular, more than $50 \%$ of all French multinational firms are concentrated in four sectors: wholesale and retail, electrical and optical instruments, machinery and equipment, and chemical products. The sectoral distribution of firms setting their first affiliate abroad (switching firms) is not significantly different from the overall distribution of all MNEs (regardless of whether they invested in a new affiliate over the 1995-2000 period or not). Differences concern only the relatively higher share of switching firms in the textile industry and lower share in chemicals and electrical and optical instruments.

\footnotetext{
${ }^{8}$ The rise in the number of multinationals is lower than the number of firms switching into multinationals, due to the fact that some firms closed down their foreign plants over the period.
} 
The Italian sample is drawn from the Reprint-dataset. Reprint is a directory, maintained by the Polytechnic of Milan and the Italian Institute for External Trade (ICE), which reports information on the identity and location of foreign affiliates of Italian multinationals. We were able to identify Italian multinational firms in the years 1993, 1995, 1997, 1999, 2000, and 2001. The number of multinationals in our sample rises from 311 in 1993 to 524 in 2001. It amounts to a rather large share of all Italian multinationals, estimated between 618 and 1,017 over the same period (Mariotti and Mutinelli, 2004). The overall number of firms setting up manufacturing affiliates abroad over the period 1993-2001 is 747, out of which 396 invested abroad for the first time (i.e. switched from national to multinational). The sectoral distribution of Italian multinational firms describes a rather different picture than in the case of France. The sectors accounting for the largest share of investment abroad are machinery and equipment, textiles and metalworking industries, while a relatively lower number of multinationals is registered in the chemical and electrical industries. This is consistent with the Italian revealed comparative advantage in traditional and specialised suppliers industries and its relative gap in high-tech industries (De Benedictis, 2005). The sectoral distribution of switching firms matches relatively well the one of overall investors, except for a relatively higher share of switching firms in the textile and leather industries (including the shoe industry, which experienced a massive process of relocation, mainly in Eastern European countries in the last decade) and a relatively smaller share in machinery industry.

Similarities and differences between French and Italian multinational firms emerge also in terms of basic firms' characteristics, such as size (as measured by the number of employees or turnover), productivity (in terms of value added per worker or total factor productivity - TFP ${ }^{9}$ ), wages (cost of labour per employee), profitability (return on investments), age, and liquidity (current ratio) reported in Table 2. ${ }^{10}$ In both countries, investing firms are much larger than switching firms (about three times larger in France and twice as large in Italy), older, exhibit higher productivity levels, and pay higher wages. This reveals that there are differences between first time investors (the switching firms) and established multinationals carrying out subsequent investments.

The comparison between the French and Italian samples also shows that French foreign investors are larger (in terms of both number of employees and turnover), older, more profitable,

\footnotetext{
${ }^{9}$ TFP has been obtained as the residual of a Cobb-Douglas value-added production function estimated for each 2digit industry using the semi-parametric technique proposed by Levinshon and Petrin (2003).

${ }^{10}$ These characteristics have been obtained from Amadeus, a well-known dataset, distributed by Bureau Van Dijk, which provides balance sheet data for a large number of firms registered in EU countries. Using the VAT code, we were able to assign those data to the multinational firms in both the French and Italian datasets.
} 
have higher labour productivity, pay higher wages, and have higher ratio of current to total assets (current ratio). These characteristics may help explain some apparently odd numbers on the number of investing (and switching) firms in the two countries. In fact, despite a larger number of multinational firms in the initial year, in France there appears to be a lower number of firms investing abroad throughout the period under investigation. This would be in contrast with official statistics on FDI flows reported by UNCTAD (2003), which show that the amount of French outward investments is twice as much the level reported by Italy. However, these data reflect the size of outward investments made by French and Italian firms, rather than the number of firms carrying out such investments projects. Our data on the size of French and Italian foreign investors support the idea that in the case of France foreign investments may be concentrated in few relatively large firms undertaking considerable investments, while in the case of Italy, the population of investing firms is larger, but each firm may be carrying out small projects. ${ }^{11}$ Furthermore, the larger number of switching firms in the Italian sample might rather pick up the fact that the degree of internationalisation of production among Italian firms has been growing quite rapidly over the nineties, while France has a longer history of internationalization of production (as confirmed by the larger number of multinationals in the initial year).

While we recognize that subsequent investments may have important effects on home plants, we believe that there are theoretical and methodological reasons to prefer a focus on switching firms. First, as illustrated in Fig. 1, our research question is about the effect of a discrete change in internationalization status on performance on the firm's home activities, as opposed to no change. In this perspective, we believe that the discrete change of a firm becoming a multinational is qualitatively different from further expansions abroad of established multinationals and is likely to capture most of the changes in the organization of production induced by foreign investment. Second, by focusing on first time investors, we avoid picking up a spurious relation stemming from the lagged effect of previous investments. Therefore, we prefer to keep a narrower (but probably sharper) scope to our analysis by focusing on switching firms only. ${ }^{12}$

\footnotetext{
${ }^{11}$ Comparable evidence on the size of investments of French and Italian multinationals is not available, but data on exports suggest that French exports are much more concentrated in fewer large firms than it is for Italy. Mayer and Ottaviano (2007) report that the largest $10 \%$ of exporters account for $84 \%$ of overall exports in France and $72 \%$ in Italy. This is the result of a lower propensity to internationalize among French small and medium sized firms.

${ }^{12}$ However, we have also carried the empirical analysis on all investors. Results, not shown in the paper, but available from the authors upon request, are qualitatively similar to those reported for the sub-sample of switching firms and in most cases the effect of investing abroad turn out even larger.
} 
Table 1 provides more details on the samples of French and Italian firms. First of all, we need to take into account that, due to missing values, not all the switching firms can be used in the econometric analysis on the effect of switching on performance at home. In fact, in order to construct the counterfactual, we need information on a large set of firm characteristics in the year before the investment abroad occurs. This imposes a large data requirement and forces us to drop about $25 \%$ of the initial sample, leaving us with 171 switching firms in the French sample and 269 in the case of Italy. However, descriptive statistics reported in Tables 1 and 2 support the idea that this sample selection does not bias our analysis in any significant way: the sectoral distribution and the characteristics of switching firms remain virtually unchanged in the smaller sample.

Using information on the country where switching firms set up their first foreign affiliate, we are able to distinguish firms switching into developing and less developed countries (LDCs) and firms switching into developed countries (DCs). Differences emerge in the geographical distribution of investments in the two countries. In particular, Italy reveals a much higher propensity towards investments in LDCs, while French firms are equally split between those investing in DCs and in LDCs. A closer inspection to the data by destination (not shown in the paper), also reveals that within LDCs, Italian firms exhibit a high propensity to invest in Eastern Europe, while French firms have a relatively higher propensity to invest in other LDCs (mostly former French colonies or French speaking countries).

As far as the distribution by sector of the switching firms is concerned, Table 1 suggests another important difference between France and Italy. While in the Italian case, there is remarkable difference in the distribution of firms switching towards LDCs and those switching in DCs (the former are relatively more concentrated in textiles and the latter in machinery, metalworking, chemicals and electrical instruments), in the French case the distribution by sector does not seem to differ much. As we will argue later, this might reflect the fact that most Italian investments towards LDCs are indeed VFDI in sectors (such as textiles) where the process can be vertically fragmented and cheap labour is a key factor of production, while in the French case investments in LDCs may be more likely to mix up some HFDI and VFDI.

The samples of switching firms drawn from Reprint and 'Enquêtes filiales' have been complemented with two samples of Italian and French-owned firms, which had no foreign affiliates, nor invested abroad in the period considered. These 'national firms' will be used to construct our counterfactual. We first utilized the whole set of national firms with more than 20 employees available in Bureau Van Dijck’s Amadeus database for both countries. However, we realized that with this criteria the control group would be too large and we would get a very poor 
prediction of the probability of investing abroad, which would result in a very poor matching. We worked this problem around by randomly drawing 25\% of firms in the original sample and ended up with 42,969 and 28,437 firm-year control observations for France and Italy, respectively. Taking into account missing values, the actual number of observations on national firms used as control group dropped to 28,645 for France and 17,219 for Italy.

\section{Results}

\subsection{Construction of the counterfactual}

As discussed earlier, the first step of our empirical analysis is the construction of an appropriate counterfactual. In fact, the plain comparison of national and switching firms might yield very misleading outcomes due to the self-selection of investing firms. In other words, switching firms are likely to be very different from the average national firm. Tables 1 and 2 provide a simple illustration of the ex-ante differences between those groups of firms. In particular, one may notice that the sectoral distribution of switching firms differs from the one of national firms. In France, about $40 \%$ of firms are in the wholesale industry, while only $20 \%$ of switching firms operate in this sector. Conversely, switching firms are relatively more concentrated in machinery and equipment, electrical and optical instruments, and chemicals than national firms. Similarly, in Italy, the share of switching firms in the textile, leather and machinery, and equipment industries is much larger than the share of national firms. This is consistent with the idea that sectoral characteristics (such as transport and fixed costs, and knowledge capital) are a major determinant of the internationalisation of production (Barba Navaretti and Venables, 2004). Nevertheless, differences in firm characteristics seem also to matter. Switching firms are (on average) much larger (in terms of employment and sales) than firms remaining national, both in France and Italy. Remarkable differences emerge also in terms of TFP, labour productivity, wages, profitability, and age. As previously mentioned, this is broadly consistent with the recent theories of international trade with heterogeneous firms ${ }^{13}$ and with recent comparative evidence on European countries (including France and Italy) reported by Mayer and Ottaviano (2007).

Our analysis is complicated by the fact that firms switching into LDC are different from those switching in DC. In particular, from Table 2 we gather that, both in France and Italy, the latter tend to be larger, more productive and profitable, pay higher wages, and exhibit higher liquidity than the former. This is consistent with the idea that firms carrying out VFDI, which are

\footnotetext{
${ }^{13}$ It is worth saying that Table 2 does not provide a formal test of the self selection hypothesis, since it only reports unconditional differences in the characteristics of firms with different degrees of internationalization of production. We defer the reader to the discussion of Table 3 for more formal evidence on this.
} 
usually more likely when firms set up plants in LDC, may be incurring lower sunk costs and the increase in efficiency gained by the access to cheap factors of production may also allow relatively less productive firms to carry out this strategy (Head and Ries, 2003). We take this into account by considering switching as a multiple treatment: firms can switch in either LDC or DC and the counterfactual group for these two types of firms needs to be different.

We run a multinomial logit regression of the probability of either remaining national, switching into LDC, and switching into DC, as function of firms' attributes such as size, age, TFP, return on investments, cost of labour per employee, the ratio of current assets to current liabilities, and a vector of sector, regional, ${ }^{14}$ and year dummies. Explanatory variables are lagged one year. We run separate regressions for the French and Italian samples pooling all observations from the various years. The results of the estimations are reported in Table A.1 of the Supplementary Material section (available on-line at the OUP website) and support the key role of TFP, which affects the probability of switching in LDC and DC in both countries. In the case of France we also find that larger firms have a higher probability to invest both in LDC and DC, while higher wages (possibly capturing a skill premium) seem to affect the probability of switching towards DC. In the case of Italy, we find that size plays a role in investing in DC, while firms investing in LDC are not necessarily the larger ones. Furthermore, switching in LDC seems more likely in less profitable firms, suggesting that switching towards LDC may be a defensive strategy. Unlike France, Italian firms investing abroad seem to be the ones paying lower wages.

The multinomial logit estimation allowed us to compute, for each firm, the probability of remaining national and the probability of switching into DC and LDC. With these propensity scores we were able to run our matching algorithm. We choose to run a nearest neighbour matching, which, for each switching, finds the control firm with the closest propensity score. In addition, we perform our matching year-by-year and sector-by-sector. This ensures that each firm from sector $j$ switching at time $t$ is matched with an observation at time $t$ from a firm within the same sector $j$. As discussed in section 3, we rely only on national firms as a counterfactual. We first run our matching algorithm on firms switching in DC, using national firms as a control group, then we matched firms switching in LDC, using again the sample of national firms as a control group.

Matching techniques assume conditional independence that is we need to rule out that the choice of investing abroad is significantly affected by unobservable variables, which also

\footnotetext{
${ }^{14}$ A dummy is included for each French department and for each Italian province.
} 
determine post-investment performance. This is not easy to ensure and test in empirical work, mainly due to data limitation. Here, we tried to control for as many observable firms' characteristics as possible (including a large set of sector and regional dummies) given our data constraint. We reached a satisfactory result in terms of explained variance, as indicated by a pseudo- $\mathrm{R}^{2}$ of 0.257 for the multinomial logit for France and 0.192 for Italy, which is in line with most existing works using matching techniques. A good matching should also result in characteristics of the counterfactual as close as possible to those of the investing firms. In formal terms, the matched sample should satisfy the balancing property, that is, the distribution of the vector of observables should be balanced across switching and control firms. We ran various tests to verify that the balancing property holds. First, we checked that no significant differences in means remain in none of the characteristics used to compute the propensity scores between switching firms and the matched control. Second, we tested for the equality of the distribution for all those variables in the switching and control groups, using a Kolmogorov-Smirnov test of equality of distributions among treated and control groups. Results, reported in Table A.2, support the hypothesis that no differences in means, nor in the shape of the distribution, remain in the switching and control groups after matching. Further tests, all reported in the supplementary online appendix, provide strong evidence that the matching algorithm allowed us to find a good control group. Figures A1a and A1b and Table A3 illustrate some statistics on the propensity scores (i.e. the probability of switching) estimated for all the firms in our French and Italian samples. They support the idea that the group of unmatched national firms has a very low probability of switching (the distribution is very skewed to the left), but the distribution of the propensity score in the subsample of matched national firms is always very similar to the one of switching firms. The difference in propensity score between switching and matched control, reported in Table $\mathrm{A} 3$, is on average lower than $1 \%$ and even at the $90^{\text {th }}$ percentile does not exceed 3.2\%. Similarly, Table A4 shows that the distribution of the characteristics in the group of switching firms is very different from the one in the group of national firms, but once the matched group is considered, differences vanish. Figures A2a and A2b illustrate this for TFP and employment rather clearly.

\subsection{The effect of investing abroad}

Once defined the appropriate counterfactual, we are ready to test for the effects of investing abroad on performance at home in our samples of French and Italian firms. As we discussed above, we compute both the average treatment effect on firms switching towards LDC and to those switching to DC (ATT), but we also control for pre-switching dynamics of performance 
abroad by computing a difference-in-difference estimator (DID). Our outcome variables are four indicators of firms' economic performances: value added, output (measured by total sales), employment, and TFP. There are obvious relations among these indicators, such as for example the effect of an expansion in output on employment and on productive efficiency (through economies of scale), or the impact of an increase in TFP on output (through an increase of international competitiveness or employment via a factor mix reallocation). Here we just concentrate on a robust estimation of the partial effect of investing abroad on these indicators, without discussing their inter-linkages and the channels through which these effects occur.

Results are presented in Table 3. For our four indicators, we report the average difference in performance between the switching and the matched controls in the first year following the investment (i.e. in $t+1$ ), as well as over a two and three years horizon. DID is computed by comparing post-investment performance at the various time horizons with the corresponding value two-years prior to switching (i.e. the year before our matching exercise). The number of cases available for the estimation varies for each variable and time frame, due to missing values. Standard errors for these means are computed by bootstrapping (100 repetitions).

The main result from our empirical analysis is that we find no evidence of negative effects of investing abroad on firms' performance. ${ }^{15}$ On the contrary, we have some evidence that firms investing abroad for the first time increase productivity, output, and employment at home, as opposed to their counterfactual and this gap seems to widen over time.

As for FDI to LDCs we observe a relatively different pattern for the two countries. In Italy we find that firms that create their first foreign plant in a LDC experience a significant increase in TFP: three years after their investment, TFP is on average $13.8 \%$ higher than the one of the control group (although if we take into account pre-switching differences, this gap reduces to $4.0 \%$ and turns non significantly different from zero). This is consistent with the idea that vertical investment implies the transfer of the (low-skill) labour-intensive activities to cheap labour countries, while the high-value added activities are kept in the home country. The dynamics of value added of the Italian firms switching towards LDC would confirm this prediction. In fact, our result suggest that value added grows faster in the latter group of firms than in the control group. Finally, we have some evidence that employment drops just after investment (however the effect is not statistically significant), but it rapidly recovers, and three years later it is $8 \%$ higher than in the control group (and marginally significant). This is likely to follow from the dynamics of value added, which after controlling for pre-investment values

\footnotetext{
${ }^{15}$ This result is robust to many alternative specifications of the selection equation and different matching strategies.
} 
(DID), three years later output is on average 9.4\% higher in the switching firms than in the control group. These results are anyway consistent with the prediction of the VFDI model that fragmentation may lead to a medium term increase in home efficiency as labour intensive activities are transferred abroad and then to long term gains in competitiveness, output, and employment. The results for France are not as clear cut. DID estimates suggest that firms investing in LDCs have higher output and employment than their counterfactual, but the effects on value added and TFP are not significant. ${ }^{16}$ One way to interpret these different findings for Italy and France is, as argued earlier, that in the former country investment to LDCs is indeed a good proxy of vertical FDI, while in the latter, there might be more of a mix of horizontal and vertical FDI. This hypothesis finds some support in the distribution of investing firms according to sector of origin of the parent in both countries. Table 1 shows rather clearly that a large proportion of Italian firms switching towards LDC are indeed concentrated in textile industries (where vertical fragmentation of production is possible and convenient), while firms switching in DC are disproportionately concentrated in Machinery and Chemicals (where market access FDI are more likely). On the contrary, in the French case, the sector distribution of firms switching in LDC and DC is not so remarkably different.

As for investments to DCs, here we find a consistent evidence both for France and Italy. Firms investing in DC experience a higher turnover after investment relative to the control group. Furthermore, this growth gap widens over time: the year after switching, output in the treated group is about $14.7 \%$ higher than in the control group in France (and 13\% in Italy), while this difference reaches $26.4 \%$ (23\%) three years after investment. This is consistent with the idea that investments in developed countries allow for a better access to foreign markets, thus fostering the need for headquarter services and export of intermediates from the parent company to the subsidiaries, as well as with a bandwagon effect on other products of the investing firms, still produced in the home country. It is also worth mentioning that we observe significant positive effects on employment at home for firms switching towards DC, both in France and Italy. These results are consistent with the HFDI model, whereby most of the gains expected from FDI should arise through scale effects.

\section{Conclusion}

This paper studies the effects of foreign investments on the size and efficiency of home activities of foreign investing firms. We compare the home performance of a sample of French and Italian

\footnotetext{
${ }^{16}$ Hijzen et al. (2006), who use a different sample of French firms, find similar results in the longer run, but the short term effects on home employment of investing in low income locations is not significant.
} 
firms which have invested abroad for the first time in the period observed to the one of a counterfactual of firms which have not invested abroad. We distinguish between investments in cheap labour countries and in advanced countries. This distinction is important for two reasons. The first one is that the former are of greater policy concern, as there is a generalised fear in continental Europe that investments to cheap labour countries are used to displace production and accelerate the on-going process of de-industrialisation, especially in manufacturing. The second one is that the distinction between the areas of destination reflects different investment motives. Investments towards cheap labour countries generally reflect the aim of saving on labour costs and they are of a vertical type, which also implies a geographical fragmentation of production. Investments towards developed countries are normally market seeking, they are therefore of a horizontal type, implying a partial or complete duplication of production stages at home and abroad. These different types of investments are also expected to have different effects on the home activities. Vertical investment essentially causes a change in the factor mix of production at home and a shift towards skill intensive activities. Horizontal investment affects home productivity, output, and employment through scale effects.

The problem of this type of analysis is of course defining the right counterfactual. For the welfare of the home country what matters is what would have happened to investing firms if they had not invested. By using propensity score matching, we can construct a counterfactual of national firms that never invest abroad which replicates this hypothetical performance. A note of caution is required. Given this framework our results do not measure the sign of the absolute performance of the firms analysed, in other words whether their absolute performance has improved or worsened. They merely say whether, whatever the sign of the absolute performance, the relative performance is different for investing and non investing firms.

The main finding is that there is no evidence of a negative effect of outward investments to cheap labour countries. In Italy, they enhance the efficiency of home activities, with also positive long term effect on value added and employment growth. This pattern is consistent with the theory of vertical investment. The geographical fragmentation of production is expected to change the factor mix of home activities, with a concentration on skill and technology intensive tasks. This may lead to an increase in productivity and value added in the short term. The consequent gains in efficiency could then enhance the competitiveness of investing firms leading to a long term expansion of home employment. For France we find a positive effect on the size of domestic activity (output and employment), but no significant effects on productivity. This may have to do with the fact that French FDI towards LDC seem to be less frequently of the 
vertical type. Investments to developed economies from both countries have instead essentially scale effects but which do not trickle down on productivity at home. These findings imply that foreign investment is often a strategic moves undertaken to strengthen home activities. In this perspective, actions aimed at discouraging foreign investments and the creation of foreign employments seem short sighted and they risk at weakening the domestic economy rather than strengthening it.

\section{Supplementary Material}

Supplementary material (Figs A1-A2 and Tables A1-A4) is available online at the OUP website.

\section{Acknowledgements}

This paper benefited from comments received at ETSG 2005 Conference, at the Third Conference of the CEPR-RTN "Trade, Industrialization and Development" in January 2006, at the EARIE 2006 and EIIE 2007 Conferences and at INSEE, UNCTAD and INRA seminars. It was previously circulated as a Centro Studi Luca d'Agliano Development Studies Working Paper 215 in May 2006 and as a CEPR Discussion Paper 5765 in July 2006. It was produced as part of the Centro Studi Luca d’Agliano Research Program in International Trade Factor Mobility and Industrialisation partly funded by the European Commission and the Compagnia di San Paolo. The authors wish to thank Laura Anselmi and Claudio Colacurcio at ICE for very skilful research assistance in building the data set for Italy.

\section{References}

Amiti, M. and Wei, S-J. (2005) Fear of Service Outsourcing: Is it Justified?, Economic Policy, 20, 308-47.

Arnold, J. and Hussinger, K. (2005) Export Behavior and Firm Productivity in German Manufacturing. A Firm-Level Analysis, Review of World Economics, 141, 219-43.

Arnold, J. and Javorcik, B.S. (2005) Gifted Kids or Pushy Parents? Foreign Acquisitions and Plant Performance in Indonesia, Discussion Paper No. 5065, CEPR, London.

Aubert, P. and Sillard, P. (2005) Offshoring and Job Losses in French Industry, Working Paper No. 3, INSEE, Paris.

Barba Navaretti, G. and Castellani, D. (2003) Investments abroad and Performance at Home: Evidence from Italian Multinationals, Discussion Paper No. 4284, CEPR, London.

Barba Navaretti, G. and Castellani, D. (2008) Do Italian Firms Improve Their Performance at Home by Investing Abroad?, in S. Brakman, H. Garretsen (eds) Foreign Direct Investment and the Multinational Enterprise, MIT Press, Cambridge, MA.

Barba Navaretti, G. and Venables, A.J. (2004) Multinational Firms in the World Economy, Princeton University Press, Princeton, NJ. 
Becker, S.O., Ekholm, K., Jäckle, R., and Muendler, M.A. (2005) Location Choice and Employment Decisions: A Comparison of German and Swedish Multinationals, Review of World Economics, 141, 693-731.

Blomström, M., Fors, G., and Lipsey, R. (1997) Foreign direct investment and employment: Home country experience in the United States and Sweden, Economic Journal, 107, 1787-97.

Blonigen, B. (2001) In search of substitution between foreign production and exports, Journal of International Economics, 53, 81-104.

Blundell, R., Costa Dias, M., Meghir, C., and Van Reenen, J. (2004) Evaluating the Employment Impact of a Mandatory Job Search Assistance Program, Journal of European Economic Association, 2, 569-606.

Boulhol, H. and Fontagné, L. (2006) Deindustrialisation and the fear of relocations in the industry, Working Paper No. 07, CEPII, Paris.

Braconier, H. and Ekholm, K. (2002) Competition for Multinational Activity in Europe: The Role Played by Wages and Market Size, Manuscript, National Institute of Economic Research, Stockholm.

Braconier, H., Ekholm, K., and Midelfart-Knarvik, K-H. (2001) Does FDI work as a channel for R\&D spillovers? Evidence based on Swedish data, Review of World Economics, 137, 644-65.

Brainard, L. and Riker, D. (1997a) Are US Multinationals Exporting US Jobs?, Working Paper No. 5958, NBER, Cambridge, MA.

Brainard, L. and Riker, D. (1997b) US Multinationals and Competition from Low Wage Countries, Working Paper No. 5959, NBER, Cambridge, MA.

Bruno, G. and Falzoni, A. (2000) Multinational Corporations, Wages and Employment: Do Adjustment Costs Matter?, Discussion Paper No. 2471, CEPR, London.

Cantwell, J. (1995) The Globalisation of Technology: What Remains of the Product Cycle Model, Cambridge Journal of Economics, 19, 155-174.

Castellani, D., Mariotti, I., and Piscitello, L. (2008) The impact of outward investments on parent company's employment and skill composition: Evidence from the Italian case, Structural Change and Economic Dynamics, 19, 81-94.

Clerides, S.K., Lach, S., and Tybout, J.R. (1998) Is Learning by Exporting Important? MicroDynamic Evidence from Colombia, Mexico, and Morocco, Quarterly Journal of Economics, 113, 903-48.

Daveri F. and Jona-Lasinio, C. (2007) Off-shoring and productivity growth in the Italian manufacturing industries, Working Paper No. 08/2007, University of Parma, Parma.

Debaere, P., Lee, H., and Lee, J. (2006) Does Where you Go Matter? The Impact of Outward Foreign Direct Investment on Multinationals’ Employment at Home, Discussion Paper No. 5737, CEPR, London.

De Benedictis, L. (2005) Three Decades of Italian Comparative Advantages, The World Economy, 28, 1679-709.

Desai M.A., Foley, C.F., and Hines Jr., J.R. (2005) Foreign Direct Investment and Domestic Economic Activity, Working Paper No. 11717, NBER, Cambridge, MA. 
Dunning, J. (1993) Multinational Enterprises and the Global Economy, Addison Wesley, Wokingham.

Egger, P. and Pfaffermayr, M. (2003) The Counterfactual to Investing Abroad: An Endogenous Treatment Approach of Foreign Affiliate Activity, Working Paper No. 02, University of Innsbruck, Innsbruck.

Feenstra, R. and Hanson, G. (1996) Foreign Investment, Outsourcing and Relative Wages, in R. Feenstra, G. Grossman and D. Irwin (eds.), Political economy of trade policy: Essays in honor of Jagdish Bhagwati, MIT Press, Cambridge, MA.

Fontagné, L. and Lorenzi, J-H. (2005) Désindustrialisation, Délocalisations, Rapport pour le Conseil d’Analyse Economique No. 55, Paris.

Girma, S. and Görg, H. (2004) Outsourcing, Foreign Ownership, and Productivity: Evidence from UK Establishment Data, Review of International Economics, 12, 817-832.

Girma, S., Greenaway, D., and Kneller, R. (2004) Does Exporting Lead to Better Performance? A Microeconomic Analysis of Matched Firms?, Review of International Economics, 12, 855-66.

Girma, S., Kneller, R., and Pisu, M. (2007) Do exporters have anything to learn from foreign multinationals?, European Economic Review, 51, 993-1010.

Görg, H., Hanley, A., and Strobl, E. (2008) Productivity effects of international outsourcing: Evidence from plant level data, Canadian Journal of Economics, 41, 670-88.

Hanson, G. H., Mataloni Jr., R.J., and Slaughter, M.J. (2003) Expansion Abroad and the Domestic Operations of U.S. Multinational Firms, Manuscript, Tuck School of Business at Dartmouth, Hanover, NH.

Harrison, A. and McMillan, M. (2006) Outsourcing Jobs? Multinationals and US Employment, Working Paper No. 12372, NBER, Cambridge, MA.

Head, K. and Ries, J. (2001) Overseas Investment and Firm Exports, Review of International Economics, 91, 108-22.

Head, K. and Ries, J. (2003) Heterogeneity and the FDI versus Export Decision of Japanese Manufactures, Journal of the Japanese and International Economies, 17, 448-67.

Heckman, J., Ichimura, H., and Todd, P. (1997) Matching as an Econometric Evaluation Estimator: Evidence from Evaluating a Job Training Program, Review of Economic Studies, 64, 605-654.

Helpman, E. (1984) A Simple Theory of International Trade with Multinational Corporations Journal of Political Economy, 92, 451-71.

Helpman, E. and Krugman, P.R. (1985) Market Structure and Foreign Trade, MIT Press, Cambridge, MA.

Helpman, E., Melitz, M., and Yeaple, S. (2004) Exports vs. FDI with heterogeneous firms, American Economic Review, 94, 300-16.

Hijzen, A., Jean, S., and Mayer, T. (2006) The Effects at Home of Initiating Production Abroad: Evidence from Matched French Firms, Manuscript, CEPII, Paris.

Konigs, J. and Murphy, A. (2006) Do multinational enterprises relocate employment to lowwage regions? Evidence from European multinationals, Review of World Economics, 142, 1-20. 
Lechner, M. (2001) Identification and estimation of causal effects of multiple treatments under the conditional independence assumption, in M. Lechner and F. Pfeiffer (eds.), Econometric Evaluation of Labour Market Policies, Physica, Heidelberg.

Levinsohn, J. and Petrin, A. (2003) Estimating Production Functions Using Inputs to Control for Unobservables, Review of Economic Studies, 70, 317-41.

Lipsey, R.E. (1999) Foreign Production by US Firms and Parent Firm Employment, Working Paper No. 7357, NBER, Cambridge, MA.

Mankiw, N.G. and Swagel, P. (2006) The politcs and economics of offshore outsourcing, Journal of Monetary Economics, 53, 1027-56.

Marin, D. (2004) A Nation of Poets and Thinkers: Less so with Eastern Enlargement? Austria and Germany, Discussion Paper No. 4358, CEPR, London.

Mariotti, S. and Mutinelli, M. (2004) Italia Multinazionale 2003, Rubbettino Editore, Soveria Mannelli.

Mariotti, S., Mutinelli, M., and Piscitello, L. (2003) Home Country Employment and Foreign Direct Investment: Evidence from the Italian Case, Cambridge Journal of Economics, 27, 419-31.

Markusen, J. (1995) The Boundaries of Multinational Firms and the Theory of International Trade, Journal of Economic Perspectives, 9, 169-89.

Mayer, T. and Ottaviano, G.I.P. (2007) The Happy Few: The Internationalisation of European Firms, Bruegel Blueprint Series, Brussels.

Molnar, M., Pain, N., and Taglioni, D. (2007) The internationalisation of production, international outsourcing and employment in the OECD, Economics Department Working Papers No. 561, OECD, Paris.

Simpson, H. (2007) Investment abroad and adjustment at home: evidence from UK multinational firms, Working Paper No. 07/07, IFS, Stockholm.

UNCTAD (2003) FDI Policies for Development: National and International Perspectives, United Nations Conference on Trade and Development, New York and Geneva.

van Pottelsberghe de la Potterie, B. and Lichtenberg F. (2001) Does Foreign Direct Investment Transfer Technology Across Borders?, Review of Economics and Statistics, 83, 490-7.

Wagner, J. (2002) The Causal Effect of Exports on Firm Size and Labor Productivity: First Evidence from a Matching Approach, Economics Letters, 77, 287-92. 
Fig. 1. Performance trajectories in home plants

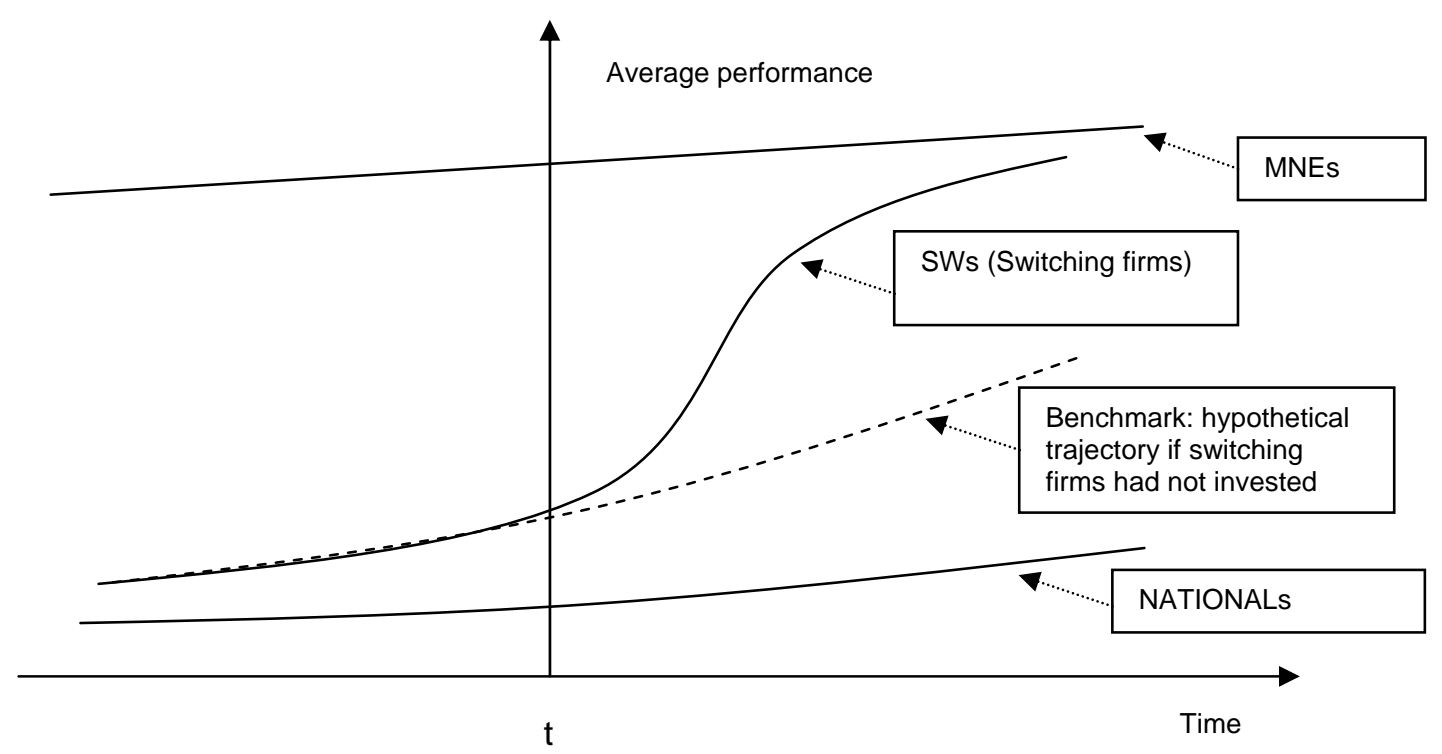

Fig. 2. Outward FDI stocks, labour productivity and employment in France and Italy over the nineties

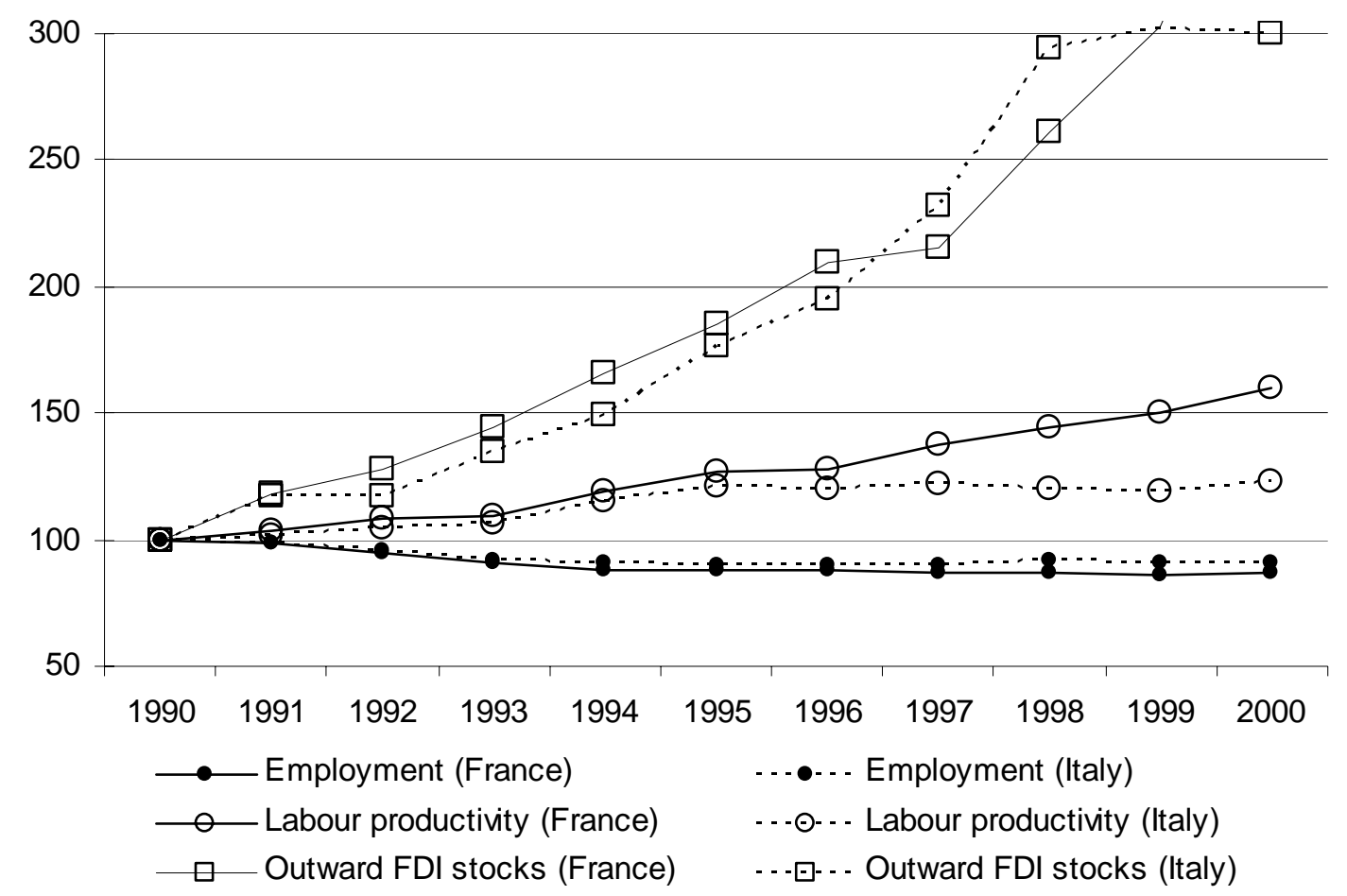

Sources: UNCTAD (http://www.unctad.org/fdistatistics) and EU-KLEMS (http://www.euklems.net/) 
Table 1. Distribution of French and Italian firms, by internationalisation status and sector

\begin{tabular}{|c|c|c|c|c|c|c|c|c|c|c|c|c|c|c|c|}
\hline & \multirow[t]{2}{*}{ Total } & \multicolumn{14}{|c|}{ Sector (\%) } \\
\hline & & $\begin{array}{l}\text { Food } \\
\text { beverages } \\
\text { tobacco }\end{array}$ & Textiles & Leather & Wood & $\begin{array}{l}\text { Paper } \\
\text { printing }\end{array}$ & Chemicals & $\begin{array}{l}\text { Rubber } \\
\text { plastic }\end{array}$ & $\begin{array}{l}\text { Other } \\
\text { non- } \\
\text { metallic }\end{array}$ & $\begin{array}{l}\text { Metals } \\
\text { metal- } \\
\text { working }\end{array}$ & $\begin{array}{l}\text { Machinery } \\
\text { equipment }\end{array}$ & $\begin{array}{l}\text { Electrical } \\
\text { optical } \\
\text { instruments }\end{array}$ & $\begin{array}{l}\text { Transport } \\
\text { equipment }\end{array}$ & $\begin{array}{l}\text { Manuf. } \\
\text { n.e.c. }\end{array}$ & $\begin{array}{l}\text { Wholesale } \\
\text { retail }\end{array}$ \\
\hline France & & & & & & & & & & & & & & & \\
\hline MNEs† & $602 / 787$ & 7.1 & 7.5 & 1.1 & 0.9 & 3.3 & 11.5 & 4.1 & 3.3 & 8.7 & 12.9 & 14.6 & 3.9 & 3.6 & 17.4 \\
\hline Investing firms & 528 & 6.4 & 5.7 & 0.4 & 0.8 & 2.1 & 17.2 & 2.8 & 2.5 & 8.7 & 10.0 & 17.0 & 4.9 & 3.2 & 18.2 \\
\hline Of which switching firms & 231 & 7.8 & 9.1 & 0.0 & 1.3 & 3.0 & 12.1 & 4.8 & 0.9 & 10.0 & 10.8 & 13.9 & 2.6 & 3.5 & 20.3 \\
\hline Italy & & & & & & & & & & & & & & & \\
\hline MNEs $\dagger$ & $311 / 524$ & 5.1 & 14.3 & 6.0 & 2.6 & 2.1 & 7.6 & 4.5 & 4.1 & 12.5 & 18.3 & 8.5 & 2.9 & 4.2 & 7.2 \\
\hline Investing firms & 747 & 5.2 & 14.3 & 4.6 & 2.4 & 2.5 & 7.5 & 4.8 & 5.2 & 12.4 & 19.1 & 8.4 & 3.0 & 4.1 & 6.4 \\
\hline Of which switching firms & 396 & 5.1 & 18.2 & 8.8 & 3.0 & 2.8 & 6.1 & 2.8 & 4.8 & 11.1 & 15.4 & 6.1 & 2.8 & 4.5 & 8.6 \\
\hline France & & & & & & & & & & & & & & & \\
\hline Switching firms & 231 & 7.8 & 9.1 & 0.0 & 1.3 & 3.0 & 12.1 & 4.8 & 0.9 & 10.0 & 10.8 & 13.9 & 2.6 & 3.5 & 20.3 \\
\hline $\begin{array}{l}\text { Switching firmsł } \\
\text { Of which: }\end{array}$ & 171 & 8.8 & 8.2 & 0.0 & 1.8 & 3.5 & 9.9 & 4.7 & 1.2 & 10.5 & 12.9 & 14.0 & 2.9 & 2.9 & 18.7 \\
\hline Switching in LDC & 80 & 8.8 & 10.0 & 0.0 & 1.3 & 3.8 & 7.5 & 6.3 & 2.5 & 12.5 & 12.5 & 11.3 & 1.3 & 3.8 & 18.8 \\
\hline Switching in DC & 91 & 8.8 & 6.6 & 0.0 & 2.2 & 3.3 & 12.1 & 3.3 & 0.0 & 8.8 & 13.2 & 16.5 & 4.4 & 2.2 & 18.7 \\
\hline National & 42,969 & 6.9 & 4.9 & 0.7 & 2.3 & 5.4 & 3.9 & 3.8 & 2.5 & 12.2 & 5.8 & 6.0 & 2.2 & 3.2 & 40.2 \\
\hline Nationalł & 28,645 & 6.7 & 4.5 & 0.6 & 2.6 & 5.7 & 3.1 & 3.6 & 2.6 & 12.6 & 4.9 & 5.0 & 1.9 & 3.2 & 43.0 \\
\hline Italy & & & & & & & & & & & & & & & \\
\hline Switching firms & 396 & 5.1 & 18.2 & 8.8 & 3.0 & 2.8 & 6.1 & 2.8 & 4.8 & 11.1 & 15.4 & 6.1 & 2.8 & 4.5 & 8.6 \\
\hline $\begin{array}{l}\text { Switching firms } \ddagger \\
\text { Of which: }\end{array}$ & 269 & 5.6 & 19.3 & 7.1 & 2.6 & 3.0 & 6.3 & 3.0 & 4.8 & 9.7 & 16.0 & 5.6 & 3.3 & 5.6 & 8.2 \\
\hline Switching in LDC & 174 & 5.7 & 24.1 & 8.6 & 2.9 & 1.7 & 4.0 & 2.9 & 5.2 & 6.9 & 14.4 & 2.9 & 2.9 & 7.5 & 10.3 \\
\hline Switching in DC & 95 & 5.3 & 10.5 & 4.2 & 2.1 & 5.3 & 10.5 & 3.2 & 4.2 & 14.7 & 18.9 & 10.5 & 4.2 & 2.1 & 4.2 \\
\hline National & 28,437 & 5.2 & 9.7 & 3.6 & 1.8 & 5.2 & 3.5 & 4.9 & 4.5 & 15.7 & 11.5 & 6.9 & 2.6 & 5.5 & 19.4 \\
\hline National $\ddagger$ & 17,219 & 5.3 & 9.9 & 3.5 & 1.8 & 5.1 & 3.5 & 5.2 & 4.6 & 15.5 & 11.0 & 6.6 & 2.5 & 5.6 & 19.8 \\
\hline
\end{tabular}

¥: Firms which have enough information on the explanatory variables to compute the propensity score. 
Table 2. Characteristics of Italian and French firms, by internationalisation status (means)

\begin{tabular}{|c|c|c|c|c|c|c|c|c|}
\hline & $\begin{array}{c}\text { Number } \\
\text { employees }\end{array}$ & Turnover & TFP & $\begin{array}{c}\text { Labour } \\
\text { productivity }\end{array}$ & $\begin{array}{l}\text { Cost of labour } \\
\text { per employee }\end{array}$ & Age & $\begin{array}{c}\text { Return on } \\
\text { investments }\end{array}$ & $\begin{array}{l}\text { Current } \\
\text { ratio }\end{array}$ \\
\hline \multicolumn{9}{|l|}{ France } \\
\hline MNEs & 687 & 183,568 & 2.32 & 68.7 & 41.1 & 33.1 & 7.11 & 1.69 \\
\hline Investing firms & 1,178 & 331,958 & 2.58 & 74.8 & 42.6 & 31.0 & 7.51 & 1.62 \\
\hline \multicolumn{9}{|l|}{ Of which: } \\
\hline Switching firms & 292 & 85,551 & 1.98 & 65.8 & 39.7 & 27.8 & 7.23 & 1.60 \\
\hline Switching firms $\ddagger$ & 286 & 87,835 & 1.95 & 64.5 & 39.7 & 28.5 & 7.56 & 1.64 \\
\hline \multicolumn{9}{|l|}{ Of which: } \\
\hline Switching in LDC & 241 & 80,124 & 1.86 & 58.9 & 37.7 & 31.8 & 7.05 & 1.56 \\
\hline Switching in DC & 326 & 94,614 & 2.02 & 69.4 & 41.4 & 25.6 & 8.02 & 1.72 \\
\hline National & 95 & 22,532 & 1.18 & 44.4 & 32.0 & 23.3 & 6.58 & 1.50 \\
\hline National $\neq$ & 89 & 21,411 & 1.18 & 44.4 & 32.0 & 24.9 & 6.67 & 1.50 \\
\hline \multicolumn{9}{|l|}{ Italy } \\
\hline MNEs & 386 & 85,788 & 2.95 & 66.8 & 33.3 & 25.9 & 5.56 & 1.32 \\
\hline \multicolumn{9}{|l|}{ Of which: } \\
\hline Switching firms & 212 & 49,403 & 2.54 & 66.4 & 31.2 & 23.6 & 6.29 & 1.28 \\
\hline Switching firms $\ddagger$ & 199 & 44,351 & 2.44 & 65.0 & 30.9 & 25.3 & 6.56 & 1.30 \\
\hline \multicolumn{9}{|l|}{ Of which: } \\
\hline Switching in LDC & 142 & 30,468 & 2.15 & 61.8 & 29.4 & 24.2 & 6.07 & 1.28 \\
\hline Switching in DC & 304 & 69,754 & 2.96 & 70.9 & 33.6 & 27.4 & 7.47 & 1.35 \\
\hline National & 75 & 17,077 & 1.58 & 50.2 & 29.7 & 20.4 & 6.26 & 1.33 \\
\hline National $\ddagger$ & 71 & 15,830 & 1.56 & 50.1 & 29.8 & 22.1 & 6.47 & 1.35 \\
\hline
\end{tabular}

‡: Firms which have enough information on the explanatory variables to compute the propensity score. 
Table 3. The effect of investing abroad on performance at home: France vs. Italy

\begin{tabular}{|c|c|c|c|c|c|c|c|c|c|c|c|c|c|c|c|c|}
\hline & \multicolumn{8}{|c|}{ France } & \multicolumn{8}{|c|}{ Italy } \\
\hline & \multicolumn{4}{|c|}{$\begin{array}{c}\text { The effect of } \\
\text { switching in LDC }\end{array}$} & \multicolumn{4}{|c|}{$\begin{array}{c}\text { The effect of } \\
\text { switching in DC }\end{array}$} & \multicolumn{4}{|c|}{$\begin{array}{l}\text { The effect of } \\
\text { switching in LDC }\end{array}$} & \multicolumn{4}{|c|}{$\begin{array}{c}\text { The effect of } \\
\text { switching in DC }\end{array}$} \\
\hline & $\begin{array}{l}\text { Nb. } \\
\text { obs. }\end{array}$ & Coef. & $\begin{array}{l}\text { Std. } \\
\text { Error }\end{array}$ & & $\begin{array}{l}\text { Nb. } \\
\text { obs. }\end{array}$ & Coef. & $\begin{array}{l}\text { Std. } \\
\text { Error }\end{array}$ & & $\begin{array}{l}\text { Nb. } \\
\text { obs. }\end{array}$ & Coef. & $\begin{array}{l}\text { Std. } \\
\text { Error }\end{array}$ & & $\begin{array}{l}\text { Nb. } \\
\text { obs. }\end{array}$ & Coef. & $\begin{array}{l}\text { Std. } \\
\text { Error }\end{array}$ & \\
\hline TFP & & & & & & & & & & & & & & & & \\
\hline ATT 1-year & 76 & 0.015 & $(0.056)$ & & 86 & 0.107 & $(0.048)$ & $* *$ & 156 & 0.110 & $(0.045)$ & $* *$ & 87 & 0.030 & $(0.049)$ & \\
\hline ATT 2-years & 70 & -0.001 & $(0.066)$ & & 79 & 0.115 & $(0.067)$ & $*$ & 143 & 0.128 & $(0.056)$ & $* *$ & 78 & 0.072 & $(0.054)$ & \\
\hline ATT 3-years & 59 & 0.005 & $(0.066)$ & & 63 & 0.145 & $(0.076)$ & $*$ & 108 & 0.138 & $(0.059)$ & $* *$ & 64 & 0.068 & $(0.059)$ & \\
\hline DID 1-year & 56 & -0.006 & $(0.053)$ & & 61 & 0.006 & $(0.035)$ & & 126 & 0.042 & $(0.031)$ & & 74 & 0.084 & $(0.038)$ & $* *$ \\
\hline DID 2-years & 50 & 0.015 & $(0.062)$ & & 55 & 0.038 & $(0.042)$ & & 113 & 0.044 & $(0.036)$ & & 65 & 0.129 & $(0.049)$ & $* * *$ \\
\hline DID 3-years & 39 & 0.010 & $(0.084)$ & & 40 & 0.073 & $(0.064)$ & & 80 & 0.040 & $(0.048)$ & & 51 & 0.108 & $(0.036)$ & $* * *$ \\
\hline Value added & & & & & & & & & & & & & & & & \\
\hline ATT 1-year & 79 & 0.182 & (0.139) & & 90 & 0.197 & $(0.150)$ & & 168 & 0.179 & $(0.102)$ & $*$ & 92 & 0.066 & $(0.081)$ & \\
\hline ATT 2-years & 78 & 0.190 & $(0.146)$ & & 88 & 0.227 & $(0.166)$ & & 162 & 0.225 & $(0.114)$ & $* *$ & 87 & 0.196 & $(0.095)$ & $* *$ \\
\hline ATT 3-years & 64 & 0.168 & (0.188) & & 73 & 0.287 & (0.153) & $*$ & 133 & 0.234 & $(0.120)$ & $*$ & 77 & 0.136 & $(0.087)$ & \\
\hline DID 1-year & 67 & 0.071 & $(0.050)$ & & 77 & 0.082 & $(0.046)$ & $*$ & 141 & 0.052 & $(0.035)$ & & 80 & 0.135 & $(0.046)$ & $* * *$ \\
\hline DID 2-years & 66 & 0.068 & (0.058) & & 75 & 0.130 & $(0.054)$ & $* *$ & 135 & 0.089 & $(0.044)$ & $* *$ & 75 & 0.253 & $(0.060)$ & $* * *$ \\
\hline DID 3-years & 52 & 0.103 & $(0.074)$ & & 60 & 0.191 & $(0.066)$ & $* * *$ & 107 & 0.094 & $(0.039)$ & $* *$ & 65 & 0.224 & $(0.066)$ & $* * *$ \\
\hline Turnover & & & & & & & & & & & & & & & & \\
\hline ATT 1-year & 79 & 0.272 & $(0.172)$ & & 91 & 0.251 & $(0.171)$ & & 172 & 0.302 & $(0.106)$ & $* * *$ & 91 & 0.101 & $(0.103)$ & \\
\hline ATT 2-years & 78 & 0.315 & $(0.184)$ & $*$ & 87 & 0.284 & $(0.200)$ & & 163 & 0.311 & (0.104) & $* * *$ & 90 & 0.113 & $(0.103)$ & \\
\hline ATT 3-years & 68 & 0.268 & $(0.223)$ & & 73 & 0.340 & $(0.165)$ & $* *$ & 133 & 0.359 & (0.118) & $* * *$ & 79 & 0.211 & (0.109) & $*$ \\
\hline DID 1-year & 66 & 0.084 & $(0.032)$ & $* * *$ & 77 & 0.147 & $(0.042)$ & $* * *$ & 147 & 0.017 & $(0.034)$ & & 80 & 0.130 & $(0.040)$ & $* * *$ \\
\hline DID 2-years & 65 & 0.121 & $(0.045)$ & $* * *$ & 73 & 0.199 & $(0.048)$ & $* * *$ & 138 & 0.012 & $(0.039)$ & & 79 & 0.150 & $(0.053)$ & $* * *$ \\
\hline DID 3-years & 55 & 0.070 & (0.065) & & 59 & 0.264 & $(0.055)$ & $* * *$ & 109 & 0.064 & $(0.051)$ & & 68 & 0.230 & $(0.059)$ & $* * *$ \\
\hline Employment & & & & & & & & & & & & & & & & \\
\hline ATT 1-year & 80 & 0.126 & $(0.168)$ & & 91 & 0.148 & $(0.171)$ & & 169 & 0.083 & $(0.104)$ & & 92 & 0.042 & $(0.097)$ & \\
\hline ATT 2-years & 78 & 0.164 & $(0.160)$ & & 88 & 0.173 & $(0.147)$ & & 159 & 0.110 & $(0.091)$ & & 90 & 0.097 & $(0.081)$ & \\
\hline ATT 3-years & 66 & 0.175 & (0.169) & & 74 & 0.211 & $(0.173)$ & & 130 & 0.186 & $(0.108)$ & $*$ & 78 & 0.056 & $(0.092)$ & \\
\hline DID 1-year & 59 & 0.061 & $(0.040)$ & & 67 & 0.132 & $(0.033)$ & $* * *$ & 142 & -0.017 & $(0.026)$ & & 79 & 0.052 & $(0.045)$ & \\
\hline DID 2-years & 57 & 0.082 & $(0.042)$ & $*$ & 65 & 0.164 & $(0.043)$ & $* * *$ & 132 & 0.022 & $(0.036)$ & & 77 & 0.143 & $(0.043)$ & $* * *$ \\
\hline DID 3-years & 45 & 0.098 & $(0.054)$ & $*$ & 51 & 0.192 & $(0.052)$ & $* * *$ & 104 & 0.080 & $(0.045)$ & $*$ & 65 & 0.127 & $(0.057)$ & $* *$ \\
\hline
\end{tabular}

Notes: Standard errors are bootstrapped (100 rep.). Asterisks denote significance levels at $1 \%(* * *), 5 \%(* *)$ and $10 \%(*)$ 